INTERNATIONAL JOURNAL OF MULTidisciplinARY RESEARCH AND ANALYSis

ISSN(print): 2643-9840, ISSN(online): 2643-9875

Volume 05 Issue 01 January 2022

DOI: 10.47191/ijmra/v5-i1-26, Impact Factor: 6.072

Page No.- 211-219

\title{
Acceptability and Usability of Quick Response Code for on Line Document Tracking in a Higher Education Institution in the Philippines
}

\author{
Michael N. Farin \\ President Ramon Magsaysay State University, Castillejos, Zambales Philippines
}

SUMMARY: The Online document tracking using Quick Response Code is an online-based program that can be accessed anywhere provided with the presence of an Internet connection. For security, username and password will be provided to the user including the level of access.

The study revealed that the school head and staff respondents' assessment was "Average" on all dimensions of the existing Practices of Documents Tracking except in terms of functionality where the staff respondent gave an evaluation of "Good". The school head respondents ' assessment on all dimensions of Quick Response Code for tracking of online documents was Excellent except on Reliability where the rating was Good. The staff respondents had given a rating of "Excellent" on all dimensions. In terms of acceptability, the school head respondents' evaluation was "Highly Accepted" while "Accepted" on performance. The staff respondents' assessment was "Highly Accepted" on the dimensions towards Quick Response Code for tracking of online documents. In terms of readiness, the school head respondents indicated that they are "ready" to use the system while the staff was "Very Ready" as to information system faculty and user/technical personnel.

Based on the summary of the investigations conducted, and the conclusions arrived at, the researcher recommended that for better document tracking, the Quick Response Code for tracking documents for President Ramon Magsaysay State University is highly endorsed and recommended for use; that the system shall be cascaded to offices to all colleges and in satellite campuses for effective and efficient tracking of documents; that the used of Quick Response Code for tracking documents is highly recommended for use which demonstrate global competitiveness and adhere to Civil Service advocacy and principle of efficient service to clients; that the used of Quick Response Code for tracking documents is highly recommended which adhere to ISO certification in providing quick, fast and efficient services and lastly to conduct a parallel or similar study with in-depth and wider in scope so as to validate the findings obtained in the study.

KEYWORDS: Acceptability, Quick Response Code, Document Tracking

\section{INTRODUCTION}

Documents may be created quickly and in large quantities using modern computing methods [1]. Methods like this are available. facilitate several versions of storing documents in a database, numerous users to work on simultaneously to the stored document. In many applications, it's useful to know who was responsible for the last update of a certain document version. Employees must enter their unique identification number before producing copies, allowing the company to track the number of copies made by each employee. Employees also provide an identification of the project they are working on in more complex systems, allowing a corporation to track costs related to certain projects. When employees have virtually unrestricted access to copy machines, it might be difficult to prevent sensitive papers from being copied. Trade secrets, employee payroll information, and company checks are all examples of sensitive papers. In most cases, a corporation will have a few people who are permitted to copy some or all of the sensitive documents, while the rest of the staff are not. Limiting a person's access to sensitive papers is a popular way to prevent unauthorized personnel from duplicating them. In more complex systems, employees can also identify the project they're working on, allowing a corporation to track costs related to certain initiatives. When employees have virtually unrestricted access to copy machines, it might be difficult to prevent sensitive papers from being copied. Trade secrets, employee payroll information, and company checks are all examples of sensitive papers. In most cases, a corporation will have a few people who are permitted 


\section{Acceptability and Usability of Quick Response Code for on Line Document Tracking in a Higher Education Institution in the Philippines}

to copy some or all of the sensitive documents, while the rest of the staff are not. Limiting a person's access to sensitive papers is a popular way to prevent unauthorized personnel from duplicating them.

However, circumstances occur wherein employees who are not authorized to copy particular sensitive documents nonetheless have access to the documents. As a result, it would be desired to create new technologies. methods of protecting sensitive documents from being copied and accessed by unauthorized persons.

In recent years and continuing, securing of information resources has been increasing, regardless of whether they are individuals or businesses. The spread of computer viruses, the availability of security flaws, the need for client information security control, and the demand for upgraded information systems are all factors driving this development. Many information security standards exist, such as ISO 15408 , ISO 17799, BS 7799 , or ISMS, and ordinary offices are implementing security policies and/or information security management. To achieve a uniform and consistent document management, "policy-based" document security systems have been developed. In these Document security policy is formed as a framework for managing document security, and documentation systems and other types of devices and equipment are linked together. In a rule table, the policy is described as a series of rules. Using the rule table, a server can provide security management for document production and/or copy jobs in an integrated manner. A document security management and maintenance system can be structured in the domain by putting the server in it. Document security is handled in this situation by document identifiers and user attributes that have been pre-registered. For computer-generated or word-processed electronic documents are only some of the requirements that organizations To take advantage of what these documents say and signify, they and their leaders must meet. In today's educational institutions, vast amounts of paperwork are frequently produced [2].

QR codes are two-dimensional barcodes that may be scanned with web-enabled mobile devices [3]. These codes link to a website, video, phone number, or text message, giving users immediate access to information resources whenever and wherever they need it. QR codes are increasingly being employed for additional useful uses in document management and, more specifically, document control [4]. You can use QR codes to direct your customers. The use of technology makes clear that organizations have begun to advances in paper documents. Documents are slowly becoming obsolete with the rise There are a variety of online solutions for viewing and maintaining online documents, as well as incorporating e-signature technology. Document management systems have unquestionable capabilities, from workflow management to document security. The advantages of a document management system are sufficient to persuade businesses to use one. If you're still not convinced, these top 6 recent trends in document management systems can just persuade you that this platform is going to play a role in the future of businesses.

For administrative and academic employees at such schools, among many others, this can be a laborious and timeconsuming process[2].

The necessity to keep track of files has grown increasingly vital in today's world, particularly in higher education institutions. However, there is little discussion of this in the literature. The majority of the time, files are physically moved from one desk to another inside a department or between departments. The File Tracking System provides a clear view of file movement throughout the file processing process (DMD, 2010). A file may need to pass through numerous people before it is deemed acceptable. However, there are disadvantages to moving these files from one desk to another, such as losing them or neglecting to document the transfer. As a result, a system that can provide solutions to such challenges while conserving administrative staff' time and energy is required. In this case, file tracking systems are a possible option. A file and document tracking software was released in 2013 [5].

The software is a simple barcode-based tracking system that is easy to use. The National Informatics Centre (NIC) in Kerala created the Information and Data Exchange Advanced System (IDEAS) as a file tracking system using Free and Open Source Software (FOSS), Karela [6]. It's a web application with the goal of keeping track of files that come into a government office, such as citizen petitions.

Through the use of a web interface, government officials can easily record or query information regarding petitions or files received at their offices via the Internet. Users, including residents and police officials, may also trace the transit of files, making the system more transparent. This system has the disadvantage of being inflexible. was designed to serve files in government offices rather than universities or other higher education organizations. One of the most pressing issues at today's universities is finding files. Time is squandered archiving or searching for files, energy is expended tracking down misplaced files, deadlines are missed, and files are occasionally lost. With these problems, the researcher came out in the decision to have an application to make a system for file tracking as the solution to solve these problems. With the objective to design and develop a file tracking system using Quick Response Code for Ramon Magsaysay State University and determine its Functional Suitability, Performance Efficiency, Compatibility, Usability, Reliability. Security, Maintainability and Portability. 


\section{Acceptability and Usability of Quick Response Code for on Line Document Tracking in a Higher Education Institution in the Philippines}

This proposal will investigate the feasibility of incorporating QR codes into an online document tracking system for use in schools, as well as the possibility of integrating QR codes into other settings. The codes serve as a link between the flat content and the internet. Despite the fact that QR codes are not as popular as some projected, the notion of the codes is maturing into image recognition (IR), which has intriguing educational applications. Teachers and students finding novel methods to use technology for learning can still use QR codes. 6

\section{EXPERIMENTAL CONSIDERATION}

\section{Research Design}

For the purpose of this study, descriptive research was used to obtain opinions of selected respondents on the evaluation of the Quick Response Code (QRC) for on line document tracking. System. Descriptive research is designed to provide a picture of a situation as it naturally happens. It was used to justify current practice and make judgement and also to develop theories [7].

The researcher focused on gathering, investigation and analysis on the procedures used by Ramon Magsaysay Technological University regarding the document and workflow management. The study will also cover the view of the head officials and staff of the university on the level of quality, acceptability and the institution's readiness of the developed system. Bhat [8] defined the descriptive research as a research technique for describing the features of the population or phenomenon being investigated. This strategy concentrates on the "what" of the study topic rather than the "why" of the investigation.

The topic of the investigation A descriptive study's purpose is to characterize a phenomena and its characteristics. This study is more interested in what happened than than how or why it happened. As a result, observation and survey tools are frequently utilized to collect data [9]. In such research, the data may be collected qualitatively, but it is often analyzed quantitatively, using frequencies, percentages and averages.

The Use Case illustrated different process and functions within the Electronic Document Management and Processing System. Similarly, the said model show the flow of the process and the relationship between them. As presented, the administrator is limited to the functions related to accounts and miscellaneous settings in the system. The staff were those personnel assigned in each offices the is only capable of organizing and managing documents. Lastly, the head in the diagram pertains to those user who's accountable and in charge in each office. They are the one who has full control and more functions within the system. Aside from the functions that was given to staff, the head had the ability to process and approved exchange of documents from and to his/her office. Moreover, they are given privilege to monitor documents changes and actions relative hereto.

\section{Research Locale and Description of the Respondents}

The study was conducted in the selected campuses of President Ramon Magsaysay State University in the province of Zambales emphasized in the illustration in Figure 6. Selected personnel from different offices of President Ramon Magsaysay State University will take part in this study. Through them the system will be evaluated and pretested. Purposive sampling was used in this study. Parahoo [10]) describes purposive sampling as "a method of sampling where the researcher deliberately chooses who to include in the study based on their ability to provide necessary data". The rationale for choosing this approach is that the researcher was seeking knowledge about the respondents' opinion on document and workflow management in which the participants provide by virtue of their experience.

The problem with taking participants is the number of respondents or the sample size. Although, there are many formulas to calculate sample size, the researcher has chosen the Slovin's formula:

Slovin's Formula:

$$
\mathrm{n}=\frac{\mathrm{N}}{1+\mathrm{NE}^{2}}
$$

Where: $\mathrm{n}=$ sample size

$$
\begin{aligned}
& \mathrm{N}=\text { population } \\
& \mathrm{E}=\text { desired margin of error }
\end{aligned}
$$

Using the formula mentioned above, given a population size of 188 and a confidence of $95 \%$, which gave a margin error of 0.05 , the sample size and distribution was then computed and shown in Table 1.

\section{Distribution of the Respondents}

There was a total respondent of 188 taken from the population of 355 school heads and staff personnel respondents. Table 1 shows the distribution of the respondents. 
Acceptability and Usability of Quick Response Code for on Line Document Tracking in a Higher Education Institution in the Philippines

Table 1. Distribution of Respondents

\begin{tabular}{|l|l|l|}
\hline Respondents & Sample Frame & Percentage \\
\hline Head & 56 & 29.79 \\
\hline Staff & 132 & 70.21 \\
\hline TOTAL & $\mathbf{1 8 8}$ & $\mathbf{1 0 0 . 0 0}$ \\
\hline
\end{tabular}

\section{Statistical Instruments}

The questionnaire was utilized as the main instrument in data gathering. The survey instrument was prepared by the researcher in consultation with his Thesis adviser and the members of the Panel. The research adopted the ISO/EC 25010:2011 for the evaluation on the effectiveness of the system. Suggestions and recommendations to further improve the questionnaires was made and adapted by the researcher. Furthermore, some items or information not considered relevant to the study was discarded. The questionnaire survey questionnaire which was distributed among the respondents consisted of three parts. The first one is the respondents' evaluation on the software quality of the Quick Response Coder for on line document tracking in terms of (i) Functional Suitability; (ii) Performance Efficiency; (iii) Compatibility; (iv) Usability; (v) Reliability; (vi) Security; (vii) Maintainability; and (viii) Portability with a rating scale as follows:

\section{RESULTS}

1. Evaluation of the School Head and Staff on the Effectiveness of the Online Documents Tracking System using Quick Response Code at President Ramon Magsaysay State University based on the ISO/IEC 20510 metrics

Table 1 shows the assessment of the school head and staff respondents on the effectiveness of the Online Documents Tracking System using Quick Response Code in President Ramon Magsaysay State University based on the ISO/IEC 20510 metrics as to functional suitability.

Table 1. Assessment of the School Head and Staff Respondents on the Effectiveness Enhanced Electronic Document Tracking System Using QR Code

\begin{tabular}{|l|l|l|l|l|}
\hline \multirow{2}{*}{ Indicators } & \multicolumn{2}{|l|}{$\begin{array}{l}\text { School Heads } \\
\text { N=56 }\end{array}$} & $\begin{array}{l}\text { Staff } \\
\text { N=132 }\end{array}$ \\
\cline { 2 - 5 } & $\begin{array}{l}\text { Weighted } \\
\text { Mean }\end{array}$ & $\begin{array}{l}\text { Descriptive } \\
\text { Equivalent }\end{array}$ & $\begin{array}{l}\text { Weighted } \\
\text { Mean }\end{array}$ & $\begin{array}{l}\text { Descriptive } \\
\text { Equivalent }\end{array}$ \\
\hline Functional Suitability & 4.27 & Excellent & 4.43 & Excellent \\
\hline Performance Efficiency & 4.15 & Good & 4.39 & Excellent \\
\hline Compatibility & 4.13 & Good & 4.32 & Excellent \\
\hline Usability & 4.29 & Excellent & 4.36 & Excellent \\
\hline Reliability & 4.08 & Good & 4.35 & Excellent \\
\hline Security & 4.32 & Excellent & 4.38 & Excellent \\
\hline Maintainability & 4.21 & Excellent & 4.29 & Excellent \\
\hline Portability & 4.16 & Good & 4.27 & Excellent \\
\hline Mean & & & & \\
\hline
\end{tabular}

The evaluation school head and staff respondents on the level of effectiveness the Online Documents Tracking System using Quick Response Code in President Ramon Magsaysay State University based on the ISO/IEC 20510 metrics as to functional suitability was similar as manifested by the overall weighted mean of 4.27 and 4.43 with descriptive equivalent of "Excellent" respectively. The staff provided higher rating of 4.39 indicating that the system is excellent in effectiveness as measured in terms of efficiency. On the other hand the school heads gave a rating of 4.15 or good. The ratings given by heads was lower by 0.24 than the rating provided by the staff. In terms of individual indicator, the highest rating of excellent was provided by staff indicating that the system has a firm response, processing time and throughput rates. The results of Lee and Harapanahali (2015)[11] indicated that the activities for document tracking and specification check can be performed more efficiently using QR codes than without QR codes.

As to compatibility, the school head officials and staff respondents assessed the level of effectiveness the Online Documents Tracking System using Quick Response Code in President Ramon Magsaysay State University based on the ISO/IEC 


\section{Acceptability and Usability of Quick Response Code for on Line Document Tracking in a Higher Education Institution}

in the Philippines

20510 metrics as to compatibility differently. With a weighted mean of 4.13 interpreted as Good, the heads had provided lower evaluation. On the hand, the staff respondents gave a rating of 4.32 with descriptive equivalent of Excellent. With a difference of 0.19 the staff had higher rating than the heads of the unit.

The school head and staff respondents assessed the level of effectiveness of the Online Documents Tracking System using Quick Response Code in President Ramon Magsaysay State University based on the ISO/IEC 20510 metrics similarly as to usability. As manifested by the overall weighted mean of 4.29 and 4.36, the heads and staff rated the system as "Excellent".

The assessment of school head on the level of effectiveness the Online Documents Tracking System using Quick Response Code in President Ramon Magsaysay State University based on the ISO/IEC 20510 metrics as to reliability was different. With the overall weighted mean of 4.08 the heads indicate that the system is "Good" but according to the staff respondents, a rating of 4.35 indicates that the system is "Excellent".

The school head and staff respondents' assessment on the level of effectiveness the Online Documents Tracking System using Quick Response Code in President Ramon Magsaysay State University based on the ISO/IEC 20510 metrics as to security was similar. With high rating of 4.32 and 4.38 , the heads and staff found that the system was excellent as to security. The result implies that the system can be easily hacked or opened by anybody who have no concern of the document.

The evaluation of the school head and staff respondents on the level of effectiveness the Online Documents Tracking System using Quick Response Code in President Ramon Magsaysay State University based on the ISO/IEC 20510 metrics as to maintainability was similar as manifested by the overall weighted mean of 4.21 and 4.29 . Although both the respondents with descriptive equivalent of "Excellent" respectively.

The evaluation of the school heads on the level of effectiveness the Online Documents Tracking System using Quick Response Code in President Ramon Magsaysay State University based on the ISO/IEC 20510 metrics as to portability was lower with a mean of 4.08 with descriptive equivalent of "Good" while a higher rating 4.35 interpreted as "Excellent" was provided by the staff respondents. A higher rating provided by the staff respondents can be attributed to their familiarity with the system that it can be installed easily and can be adapted to any other system.

\section{Assessment of the School Head and Staff Respondents on the Level of Readiness in the Implementation of the Enhanced} Electronic Document Tracking System Using QR Code

Table 2 shows the assessment of the school head and staff respondents on the level of readiness in the implementation of the enhanced electronic document tracking system using QR Code as to Information System Facility.

Table 2. Assessment of the School Head and Staff Respondents on the Level of Readiness in the Implementation of the Enhanced Electronic Document Tracking System Using QR Code

\begin{tabular}{|l|l|l|l|l|}
\hline \multirow{2}{*}{ Indicators } & \multicolumn{2}{|l|}{$\begin{array}{l}\text { School Head } \\
\text { N=56 }\end{array}$} & $\begin{array}{l}\text { Staff } \\
\text { N=132 }\end{array}$ \\
\cline { 2 - 5 } & $\begin{array}{l}\text { Weighted } \\
\text { Mean }\end{array}$ & $\begin{array}{l}\text { Descriptive } \\
\text { Equivalent }\end{array}$ & $\begin{array}{l}\text { Weighted } \\
\text { Mean }\end{array}$ & $\begin{array}{l}\text { Descriptive } \\
\text { Equivalent }\end{array}$ \\
\hline Information System Facility & 4.13 & Ready & 4.20 & Very Ready \\
\hline User/Technical Personnel & 4.11 & Ready & 4.29 & Very Ready \\
\hline Mean & & & & \\
\hline & & & & \\
\hline
\end{tabular}

The school head officials assessed the level of readiness in the implementation of the enhanced electronic document tracking system using QR Code as to Information System Facility differently. As manifested in the overall weighted mean of 4.13 with head respondents implies that they are ready for the implementation of the system. On the other hand, higher rating of 4.20 by the staff respondents implies that they "Very Ready" to use the system. .

School head respondents are more of cognitive, decision and human relation skills while staff respondents are more of the technical skills looking for suitable places and internet availability and connectivity.

The evaluation made by the school head and the staff on the level of readiness in the implementation of the enhanced electronic document tracking system using QR Code as to User/Technical Personnel was different as manifested by the overall weighted mean of 4.11 with descriptive equivalent of "Ready". On the other hand, a slightly higher rating of 4.29 from the staff respondents with descriptive equivalent of "Very Ready" was recorded.

IJMRA, Volume 5 Issue 01 January 2022 
Acceptability and Usability of Quick Response Code for on Line Document Tracking in a Higher Education Institution in the Philippines

The data implies on the very readiness of the staff respondents and this could be ascribed on their age as millennial compared to adult school heads official. Staff respondents who are graduates of computer sciences understand the computer language and could make certain trouble shooting in case there is a malfunction on the system.

1. Assessment of the School Head and Staff Respondents on the Level of Acceptability of the Quick Response Code for Tracking of On-line Documents

Table 3 shows the assessment of the school head and staff respondents on the level of acceptability of the quick response code for tracking of on-line documents as to functionality.

Table 3. Assessment of the School Head and Staff Respondents on the Level of Acceptability of the Quick Response Code for Tracking of On-line Documents

\begin{tabular}{|l|l|l|l|l|}
\hline \multirow{2}{*}{ Indicators } & \multicolumn{2}{|l|}{$\begin{array}{l}\text { School Heads } \\
\text { N=56 }\end{array}$} & \multicolumn{2}{l|}{$\begin{array}{l}\text { Staff } \\
\mathbf{N}=132\end{array}$} \\
\cline { 2 - 5 } & $\begin{array}{l}\text { Weighted } \\
\text { Mean }\end{array}$ & $\begin{array}{l}\text { Descriptive } \\
\text { Equivalent }\end{array}$ & $\begin{array}{l}\text { Weighted } \\
\text { Mean }\end{array}$ & $\begin{array}{l}\text { Descriptive } \\
\text { Equivalent }\end{array}$ \\
\hline Functionality & 4.30 & $\begin{array}{l}\text { Highly } \\
\text { Accepted }\end{array}$ & 4.30 & $\begin{array}{l}\text { Highly } \\
\text { Accepted }\end{array}$ \\
\hline Performance & 4.13 & Accepted & 4.26 & $\begin{array}{l}\text { Highly } \\
\text { Accepted }\end{array}$ \\
\hline Usability & 4.30 & $\begin{array}{l}\text { Highly } \\
\text { Accepted }\end{array}$ & 4.30 & $\begin{array}{l}\text { Highly } \\
\text { Accepted }\end{array}$ \\
\hline Mean & & & & \\
\hline
\end{tabular}

The assessment of school heads and staff respondents on the level of acceptability of the quick response code for tracking of on-line documents as to functionality was not different. The school heads had a slightly lower rating of 4.30 and the staff had a slightly higher rating of 4.35 both with a descriptive rating of "Highly Accepted". Both the respondents agree that the system is highly acceptable in the academe.

According to both groups of respondents, they had seen, observed and experienced the functionality of the proposed quick response code for tracking of on-line documents. At a lesser time of searching, they can immediately trace and track the documents. It provides detail of the documents when it was issued, date received, and the nature of the documents.

The school head and staff respondents assessed the level of acceptability of the quick response code for tracking of online documents as to functionality differently. With a weighted mean of 4.13 interpreted the heads indicate that the system is Acceptable. A higher rating of 4.26 with descriptive equivalent of "Highly Accepted", the staff found that the system is highly acceptable.

The data implies on the divergence of assessment between the two groups towards performance of the Quick Response Code for Tracking of On-line Documents. The data further shows on the very much appreciate among staff respondents as the core recipient and beneficiary of the project that would make their functions and duties more efficient, and effective. Above all, it is considered very friendly compared to the existing where they are prone to allergies while scanning bulk of papers from the drawers and filing cabinets.

The evaluation of school head officials and staff respondents on the level of acceptability of the quick response code for tracking of on-line documents as to usability was the same. The overall equal weighted mean of 4.30 and 4.30 both the respondents indicate that the system is "Highly Accepted".

Both groups agree on the high acceptability of the quick response code for tracking of on-line documents as to usability. It is very useful in improving the management of documents and provide efficient transaction for clientele requesting for document like transcript of records, office and university memoranda, CMO's, letters from the Commission on Higher Education and other government agencies.

2. Test of significant difference on the evaluation of head officials and staff respondents towards existing and proposed online Quick Response Code for tracking of on line documents for President Ramon Magsaysay State University

Table 4 shows the significant differences on the evaluation of head and staff respondents towards existing and proposed online quick response code for tracking of on line documents for President Ramon Magsaysay State University. 

in the Philippines

On the existing system, the computed Significant or $\mathrm{P}$ value (2-tailed test) equivalent to 0.000 on (functional suitability); 0.000 on (performance efficiency); 0.000 (compatibility); 0.000 on (usability; 0.000 on (reliability); 0.000 on (security); 0.000 on sustainability); and 0.000 on (portability) which all are lower than 0.05 Alpha Level of Significance, hence there is significant difference on the assessment towards the existing document tracking between the school heads and staff respondents. The staff respondents had provided a higher rating in almost all the indicators provided.

Table 4. Test of significant difference on the evaluation of head officials and staff respondents towards existing and proposed online Quick Response Code for tracking of on line documents for President Ramon Magsaysay State University

\begin{tabular}{|l|l|l|l|l|l|l|l|l|}
\hline & \multicolumn{3}{|l|}{ Existing } & \multicolumn{2}{l|}{ Proposed Online } \\
\hline Indicators & df & t Stat & $\begin{array}{l}\text { Sig. } \\
\mathbf{( 2 -} \\
\text { tailed) }\end{array}$ & Decision & df & t Stat & $\begin{array}{l}\text { Sig. } \\
\mathbf{( 2 -} \\
\text { tailed) }\end{array}$ & Decision \\
\hline $\begin{array}{l}\text { Functional } \\
\text { Suitability }\end{array}$ & 187 & 64.352 & 0.000 & Reject Ho & 187 & 150.224 & 0.000 & Reject Ho \\
\hline $\begin{array}{l}\text { Performance } \\
\text { Efficiency }\end{array}$ & 187 & 59.258 & 0.000 & Reject Ho & 187 & 59.258 & 0.000 & Reject Ho \\
\hline Compatibility & 187 & 59.442 & 0.000 & Reject Ho & 187 & 111.601 & 0.000 & Reject Ho \\
\hline Usabili1y & 187 & 59.169 & 0.000 & Reject Ho & 187 & 117.019 & 0.000 & Reject Ho \\
\hline Reliability & 187 & 58.922 & 0.000 & Reject Ho & 187 & 123.172 & 0.000 & Reject Ho \\
\hline Security & 187 & 61.236 & 0.000 & Reject Ho & 187 & 124.371 & 0.000 & Reject Ho \\
\hline Maintainability & 187 & 64.281 & 0.000 & Reject Ho & 187 & 116.347 & 0.000 & Reject Ho \\
\hline Portability & 187 & 60.584 & 0.000 & Reject Ho & 187 & 116.799 & 0.000 & Reject Ho \\
\hline
\end{tabular}

On the proposed online Quick Response Code for tracking of on line documents, the computed Significant or $\mathrm{P}$ value (2-tailed test) equivalent to 0.000 on (functional suitability); 0.000 on (performance efficiency); 0.000 (compatibility); 0.000 on (usability; 0.000 on (reliability); 0.000 on (security); 0.000 on sustainability); and 0.000 on (portability) which all are lower than (<) 0.05 Alpha Level of Significance, hence there is significant difference on the assessment towards the proposed online document tracking between the school heads and staff respondents.

The data indicates differences of the existing and proposed online quick response code for tracking of on line documents for President Ramon Magsaysay State University. The online tracking with the application of QR codes can search and trace documents without having to ask their peers or teachers. Hernández-Julián \& Peters [12], in their study conducted to compare doing homework online with doing homework on paper, found that an electronic environment could make it easier to access an instructional material and that it did not significantly influence learning. Al-Khalifa [13]) developed a Mobile Snapshot Response system with QR Codes.

The existing old system would take much time in looking for the needed old documents from filing cabinets and tracks. It cannot adhere on the government advocacy to reply request of clientele within 3 days period because of tedious activity in searching. But the proposed new online Quick Response Code for tracking of on line documents makes the work efficient and effective.

According to Knowles and David [14] it is a primary object of the present invention to provide an improved method and apparatus for Surfing among information resources on the Internet while avoiding the Shortcomings and drawbacks of prior art Systems and methodologies. A further object of the present invention is to provide an Internet Scanning System which includes an bar code Symbol reader for reading URL-encoded bar code symbols printed on various types of print media which, when read thereby, automatically connects the Internet Scanning System to the Internet Server that contains the information resource Specified by the Scanned URL-encoded bar code symbol.

3. Test of significant difference between the head officials and staff respondents on the level of acceptability in the Quick Response Code for tracking of on line documents for President Ramon Magsaysay State University

Table 5 shows the significant difference between the head officials and staff respondents on the level of acceptability in the Quick Response Code for tracking of on line documents for President Ramon Magsaysay State University 
Acceptability and Usability of Quick Response Code for on Line Document Tracking in a Higher Education Institution in the Philippines

Table 5. Test of significant difference between the head officials and staff respondents on the level of acceptability in the Quick Response Code for tracking of on line documents for President Ramon Magsaysay State University

\begin{tabular}{|l|l|l|l|l|}
\hline Indicators & df & t Stat & Sig. (2-tailed) & Decision \\
\hline Functionality & 187 & 111.292 & 0.000 & Reject Ho \\
\hline Performance & 187 & 110.974 & 0.000 & Reject Ho \\
\hline Usability & 187 & 111.292 & 0.000 & Reject Ho \\
\hline
\end{tabular}

The null hypothesis is rejected based on the computed Significant or P-values of 0.000 on (functionality); 0.000 on performance; 0.000 on usability which is lower than (<) 0.05 Alpha Level of Significance, hence there is significant difference on the assessment towards the level of acceptability on the Quick Responses Code for tracking of on online documents for the President Ramon Magsaysay State University between the school heads and staff respondents.

The computed data clearly manifest that the level of acceptability of the proposed online Quick Response Code for tracking of on line documents for the President Ramon Magsaysay State University was better compared to the existing method of tracking documents.

The Online Quick response Code for tracking documents are with application of mobile devices and QR code technology which can provide efficient and effective searching and tracking for documents. The QR codes can take m-learning to a new level, referred to as ubiquitous or u-learning, by providing exactly the right information, at the right time and place, challenging each ulearner through a unique, individualized, wireless learning environment [15].

Mobile devices and QR code symbols can offer an ideal method to provide students instant learning assistance using devices they already possess. Integrating digital and text information will bring opportunities for learners to comprehend print material by providing relevant, real-time background knowledge, while allowing students to learn at their own pace [16].

Multimedia digital content via audio/video clips provide students the ability to gather information from a variety of methods which explain concepts in greater detail. Supplementary materials in the form of QR codes give instantaneous availability to digital help via scaffolding questions to support students in the learning process [16].

4. Test of significant difference between the head officials and staff respondents' evaluation on the level of readiness in the implementation of Quick Response Code for tracking of on line documents for President Ramon Magsaysay State University.

Table 25 shows the significant difference between the head officials and staff respondents' evaluation on the level of readiness in the implementation of Quick Response Code for tracking of on line documents for President Ramon Magsaysay State University

The null hypothesis is rejected based on the computed Significant or P-values of 0.000 on (Information System Facility); and 0.000 on (User/Technical Personnel) which are lower than (<) 0.05 Alpha Level of Significance, hence there is significant difference on the assessment towards the level of readiness in the implementation of the Quick Responses Code for tracking of on online documents for the President Ramon Magsaysay State University between the school heads and staff respondents.

Table 6. Test of significant difference between the head officials and staff respondents' evaluation on the level of readiness in the implementation of Quick Response Code for tracking of on line documents for President Ramon Magsaysay State University

\begin{tabular}{|l|l|l|l|l|}
\hline Indicators & df & t Stat & Sig. (2-tailed) & Decision \\
\hline Information System Facility & 187 & 99.448 & 0.000 & Reject Ho \\
\hline User/Technical Personnel & 187 & 107.067 & 0.000 & Reject Ho \\
\hline
\end{tabular}

This finding contradicts the study of Bachillar [17] where he found out that there was no significant difference toward level of readiness on electronic document management and processing system as perceived by school heads and staff respondents.

Advances in technology have transformed the world of work. AS the work environment has changed, individual worker see how their work connects not only to their particular workplace but to the entire value chain. Merging in the fast lane of the information super highways of the $21^{\text {st }}$ century world of work. The technology explosion has transformed every level of business environment. Office technology focuses upon office information function such as word processing, data processing, graphics, desktop publishing and communication. 


\section{Acceptability and Usability of Quick Response Code for on Line Document Tracking in a Higher Education Institution}

in the Philippines

\section{CONCLUSION}

Based on the findings of the study, the researcher concludes that:

1. The enhanced on line tracking of documents using Quick Response Code is Good except on reliability which is excellent.

2. The enhanced on line tracking of documents using QR code is highly accepted.

3. The school head respondents are ready while the staff are very ready to implement the enhanced on line tracking of documents using QR code.

4. There are significant differences on the assessment between school heads and staff respondents towards dimensions on the proposed online Quick Response Code for tracking of on line documents as to functionality, performance, efficiency, capability, usability, reliability, security, maintainability and portability.

5. There is significant difference on the assessment towards the level of acceptability on the Quick Responses Code for tracking of on online documents between the school heads and staff respondents.

6. There is significant difference on the assessment towards the level of readiness in the implementation of the Quick Responses Code for tracking of on online documents between the school heads and staff respondents.

\section{Acknowledgment}

The author would like to express his thanks to Dr. Nemia Galang for her valuable advice.

\section{REFERENCES}

1) Hewlett-Packard, Exploring today's technology for tomorrow's possibilities HP.com; Timeline of our history, 2019

2) P. Kumar, S. Rao, and P. Aithal, Strategic Planning in Higher Education Institutions: A Case Study of Sims - Vision 2025.International Journal of Educational Science and Research (IJESR) ISSN(P): 2249-6947; ISSN(E): 2249-8052, Vol. 5, Issue 2, 29-42,2015

3) S. O'Connor and T. Andrews, Mobile technology and its use in clinical nursing education: a literature review, J Nurs Educ. Vol. 54(3),pp137-144,2015

4) B.Bowyer, Using QR codes in your document control work. Document, Control news and events, 2016

5) S. Telepen, File and Document Tracking System, http://telepen.co.uk/file,2013

6) I.Karela, Know the status of your files and petitions online through IDEAS, http://archives.keralaitnews.com/, 2013

7) N.Burns, N.and S. Grove, The practice of nursing research : appraisal, synthesis, and generation of evidence. St. Louis, Mo: Saunders Elsevier,2009

8) Bhat R. Descriptive Research: Definitio, characteristics, methods, examples and advantages. Retrieved from https://questionpro.com.blog/descriptive research/. Data accessed September, 2019

9) M. Gall, J. Gall, and W. Borg, , , Educational research: An introduction (8th ed.). Boston: Pearson, 2007

10) K. Parahoo, Nursing research: Principles, process and issues. Houndmills, England: Macmillan,1997

11) Lee and Harapanahali, Response Codes \& Smartphones in a Biology Field Study. The American Biology Teacher, Vol. 73, No. 8, 485-492. doi: 10.1525/abt.2011.73.8.11,2015

12) R. Hernández-Julián, and C. Peters, Does the Medium Matter? Online versus Paper Coursework. Southern Economic Journal, 78(4), 1333-1345,2012

13) Al-Khalifa, H.S. (2011). An M-Learning System Based on Mobile Phones and Quick Response Codes. Journal of Computer Science 7 (3): 427-430,2011

14) M. Knowles and W. David, Internet-Based System And Method For Tracking Objects Bearing Url Encoded Bar Code Symbols 75 United States Patent Patent Number: 5,869,819 (45) Date of Patent: Feb. 9, 1999 54,2009

15) S, Leone and T. Leo, The Synergy of Paper-Based and Digital Material for Ubiquitous Foreign Language Learners Knowledge Management \& E-Learning: An International Journal, Vol.3, No.3,2011

16) N. Chen, D. Teng, and C. Lee, Augmenting paper-based reading activity with direct access to digital materials and scaffolded questioning. Computers \& Education, 57(2),pp 1705-1715,2011

17) D. Bachillar and M. Dela Cruz Electronic Document Management and Processing System of Ramon Magsaysay State University, Unpublished Graduate Thesis, Ramon Magsaysay Technological University, Iba, Zambales, Philippines, 2017 